\title{
Meta Analisis: Model Pembelajaran PBL Terhadap Kemampuan Berpikir Kritis Matematis Siswa
}

\author{
Nikmatur Rohmah $^{1}$, Suryo Widodo ${ }^{2}$, Yuni Katminingsih ${ }^{3}$ \\ ${ }^{1,2}$ Program Studi Pendidikan Matematika, Fakultas Ilmu Kesehatan dan Sains, Universitas Nusantara PGRI Kediri \\ J1. KH. Ahmad Dahlan No 76 Kediri \\ nikmahiis0@gmail.com
}

\begin{abstract}
There are many studies to improve students' critical thinking skills through the PBL learning model, but no one has analyzed the results of the research that has been done. This study aims to determine students' critical thinking skills towards the PBL learning model. This study uses a meta-analysis method with a sample of 10 journal articles. The learning model in this study, the researchers took the Problem Based Learning (PBL) learning model. The results of the meta-analysis research show that the Problem Based Learning $(P B L)$ learning model on student's critical thinking skills has an effect size with high criteria and when looking for the average of the Problem Based Learning $(P B L)$ learning model, the average value of effect size $=1.47$ (high effect).
\end{abstract}

Keywords: Meta analysis, critical thinking skills, PBL learning model.

\begin{abstract}
Abstrak
Banyak penelitian model pembelajaran $P B L$ terhadap kemampuan berfikir kritis siswa, tetapi belum ada yang menganalisis hasil penelitian yang sudah dilakukan. Penelitian ini bertujuan untuk mengetahui kemampuan berfikir kritis siswa terhadap model pembelajaran $P B L$. Penelitian ini menggunakan metode meta analisis dengan jumlah sampel 10 artikel jurnal. Model pembelajaran pada penelitian ini peneliti mengambil Model pembelajaran Problem Based Learning (PBL). Hasil penelitian meta analisis menunjukkan bahwa model pembelajaran Problem Based Learning $(P B L)$ terhadap kemampuan berfikir kritis siswa memiliki Effect Size dengan kriteria tinggi dan bila dicari rata - rata dari model pembelajaran Problem Based Learning $(P B L)$ maka nilai rata-rata Effect Size $=1.47$ (efek tinggi).
\end{abstract}

Kata Kunci: Meta analisis, kemampuan berfikir kritis, model pembelajaran PBL

Copyright (c) 2022 Nikmatur Rohmah, Suryo Widodo, Yuni Katminingsih

$\triangle$ Corresponding author: Nikmatur Rohmah

Email Address: nikmahiis0@gmail.com (Jl. KH. Ahmad Dahlan No 76 Kediri)

Received 01 January 2022, Accepted 22 January 2022, Published 19 February 2022

\section{PENDAHULUAN}

Menciptakan generasi penerus bangsa yang cerdas dan berkarakter bidang pendidikan merupakan salah satu bidang yang mempunyai pengaruh yang penting. Hal ini sejalan dengan bunyi Undang-Undang Nomor 20 Tahun 2003 tentang Sistem Pendidikan Nasional bahwa pendidikan adalah usaha sadar dan terencana untuk mewujudkan suasana dan proses pembelajaran supaya siswa dapat mengembangkan potensi dirinya sehingga memiliki kekuatan spiritual keagaman, pengendalian diri, kepribadian, kecerdasan, akhlak mulia, dan ketrampilan yang diperlukan oleh diri sendiri, masyarakat, bangsa, dan negara.

Pendidikan merupakan proses belajar seseorang untuk merubah perilaku menjadi lebih baik (Wahyuni, Sri;Anugraheni, 2020). Mamin (Hagi et al., 2019) mengatakan bahwa kualitas pendidikan akan berjalan dengan efektif dan efisien dalam pembelajarannya dengan adanya media, bahan ajar, dan lingkungan yang memadai. Begitu juga matematika, matematika merupakan muatan pembelajaran yang penting baik bagi pendidikan, teknologi, dan bidang lainnya. Suhendri \& Ningsih mengatakan salah satu karakteristik matematika yaitu dapat diaplikasikannya matematika tersebut ke 
dalam semua bidang di kehidupan sehari-hari (H. Nanda;K, 2019). Syahbana (Sianturi et al., 2018) mengatakan matematika adalah disiplin ilmu yang mengandalkan proses berpikir yang sangat baik untuk siswa. Matematika bertujuan agar siswa terbiasa berpikir sistematis, logis, kritis, dan kreatif.

Kemampuan berfikir kritis, dan kreatif ini termasuk kemampuan pendidikan abad ke-21. Berpikir kreatif berperan penting dalam ketrampilan berpikir tingkat tinggi (Higher Order Thinking Skills). Untuk itu, kemampuan berpikir seseorang ada 2 yaitu kemampuan kreatif dan kemampuan kecerdasan. Dalam 2/3 kemampuan kreativitas seseorang adalah dari pendidikan, 1/3 dari genetik. Sebaliknya dalam kemampuan kecerdasan 1/3 diperoleh dari pendidikan, dan 2/3 sisanya dari genetik. Artinya, kita tidak dapat berbuat banyak untuk meningkatkan kecerdasan namun kita dapat meningkatkan kreativitas seseorang. Sehingga tulisan tersebut ingin memeta analisiskan penelitian berfikir kreatif (Widodo et al., 2021).

Namun, pembelajaran ini lebih menekankan pembelajaran matematika pada siswa untuk berpikir kritis (Sianturi et al., 2018). Berpikir kritis adalah kemampuan berpikir tingkat tinggi yang dimiliki seseorang untuk memecahkan suatu masalah dengan logis dan tepat (Wahyuni, Sri;Anugraheni, 2020). Untuk itu, peneliti menggunakan kemampuan berpikir kritis pada pembelajaran matematika menjadi komponen penting bagi siswa. Hal ini agar siswa mampu membuat dan merumuskan, mengidentifikasi, menafsirkan dan merencanakan pemecahan masalah (Agustina et al., 2018). Ennis juga mengatakan, berpikir kritis merupakan proses berpikir dengan tujuan untuk membuat keputusan-keputusan yang masuk akal mengenai apa yang harus dilakukan dan apa yang harus dipercayai (Nurlaeli et al., 2018). Kemampuan berpikir kritis, siswa akan mampu menerapkan konsep ke dalam kondisi kehidupan sehari-hari baik untuk beradaptasi maupun untuk sebuah tantangan dengan efektif dan efisien. Apabila siswa tidak dapat berpikir kritis dalam hal mengkomunikasikan matematika, hal tersebut dikarenakan faktor proses pembelajarannya serta faktor diri sendiri.

Faktor proses pembelajaran cenderung satu arah, dimana seharusnya pembelajaran matematika menggunakan 2 aspek yaitu belajar dan mengajar. Dalam proses pembelajaran matematika, siswa harus dilibatkan secara aktif dan berlangsung dalam konteks sosial maka kemampuan berpikir kritis matematika siswa dapat meningkatkan dengan baik sesuai dengan yang diharapkan(Simarmata, 2019). Fajarwati \& Manoy menjelaskan bahwa adanya permasalahan merupakan salah satu upaya yang dilakukan untuk meningkatkan kemampuan berpikir kritis matematis siswa, dengan begitu mereka akan berusaha berpikir untuk mencari solusi dari masalah tersebut sebagai penyelesaiannya.(Yanti \& Prahmana, 2017)

Dari beberapa model pembelajaran berdasarkan masalah, salah satunya adalah model PBL,model ini adalah model yang mengarah pada pemecahan masalah yang diharapkan dapat mengasah berpikir kritis siswa. PBL akan membantu siswa dalam berpikir kritis, mengatasi masalah, mempelajari peran serta menjadi pelajar yang mandiri (Amalia \& Pujiastuti, 2016). Model ini digunakan untuk konteks belajar berpikir kritis dan terampil dalam memecahkan suatu masalah 
Meta Analisis: Model Pembelajaran PBL Terhadap Kemampuan Berpikir Kritis Matematis Siswa, Nikmatur Rohmah, Suryo Widodo, Yuni Katminingsih

(Sudarman, 2007). Karakteristik Problem Based Learning menurut Barrows ada 6 diantaranya: (1) Proses pembelajaran bersifat Student-Centered; (2) Proses pembelajaran berlasung dalam kelompok kecil; (3) Guru berperan sebagai fasilitator atau pembimbing; (4) Permasalahan yang disajikan dalam setting pembelajaran diorganisasi dalam bentuk dan fokus tertentu yang merupakan stimulus pembelajaran; (5) Informasi baru diperoleh melalui belajar secara mandiri (Self-directed learning); dan (6) Masalah (problems) merupakan wahana untuk mengembangkan keterampilan pemecahan masalah klinis (Fristadi \& Bharata, 2015). Keberhasilan metode ini mengatakan bahwa penerapan model ini mampu meningkatkan kemampuan berpikir kritis dan hasil belajar Data dikumpulkan dengan menggunakan soal evaluasi dan lembar observasi. (Febrita \& Harni, 2020).

Dari model pembelajaran Problem Based Learning (PBL) tersebut terdapat pengaruh terhadap kemampuan berpikir kritis. Oleh sebab itu, peneliti tertarik melakukan meta analisis terhadap artikel jurnal atau tesis, tentang model pembelajaran Problem Based Learning (PBL) dan bertujuan untuk mengetahui kemampuan berfikir kritis siswa terhadap model pembelajaran Problem Based Learning $(P B L)$. Hasil meta analisis ini diharapkan dapat memberi keseragaman pandangan atas temuan secara menyeluruh.

\section{METODE}

Jenis penelitian yang digunakan adalah meta-analisis. Meta analisis tersebut merupakan penelitian dengan cara merangkum data peneliti, mereview, dan menganalisis data penelitian dari beberapa hasil penelitian yang sudah ada sebelumnya. Analisis meta ini dapat digunakan untuk menganalisis penelitian empiris yang sudah dilakukan peneliti sebelumnya, hasil penelitian kuantitatif, hasil penelitian dalam bentuk yang dapat dibandingkan misalnya rerata, koefisien korelasi, dan odds-ratio. Hasil penelitian dijadikan bahan untuk menghitung effect size, yang digunakan untuk menyusun agregat. Analisi ini juga digunakan untuk menguji hubungan dan konstruk yang dapat dibandingkan. Analisis meta ini adalah metode penelitian khusus untuk menggabungkan penelitian yang dapat diukur effect size-nya. Analisis meta tersebut hanya menganalisis penelitian kuantitatif, dimana penelitian kuantitatif tersebut merupakan penelitian yang menggunakan pengukuran kuantitatif dari suatu viariabel dan melaporkan statistik deskriptif atau inferensial untuk menjelaskan hasil penelitian (Widodo et al., 2021). Pengumpulan data penelitian menggunakan study kepustakaan (library research) dengan cara pencarian artikel-artikel yang terdapat di jurnal online melalui Google Scholar atau Cendekia. Dengan kata kunci "kemampuan berfikir kritis, model pembelajaran pbl", kemudian dipilih artikel yang memenuhi kriteria model pembelajaran Problem Based Learning (PBL) untuk meningkatkan kemampuan bepikir kritis.Populasi penelitian ini adalah artikel-artikel yang sudah dipublikasi.Sampel yang digunakan merupakan jurnal yang membahas model pembelajaran Problem Based Learning (PBL) terhadap kemampuan berfikir kritis siswa.Jurnal yang digunakan dari 
jenjang pendidikan SD sebanyak 1 artikel, SMP sebanyak 6 artikel,SMA sebanyak 3 artikel yang terdapat pada jurnal pendidikan matematika.

Teknik analisis data yang digunakan dalam penelitian ini adalah teknik analisis besar pengaruh atau effect size. Rumus effect size yang digunakan adalah formula pengaruh (effect size) dengan rumus sebagai berikut:

$$
\text { effect size }=\frac{\text { mean of experimental group-mean of control group }}{\text { standard deviation of the control group }}
$$

Hasil perhitungan nilai effect size Cohen's diinterpretasikan dengan kriteria Cohen's (Cohen et al., 2013) sebagai berikut:

Tabel 1. Kategori Nilai Effect size Cohen's

\begin{tabular}{|c|c|c|}
\hline No & Nilai ES & Kategori \\
\hline 1 & $0-0,20$ & Efek sangat rendah \\
\hline 2 & $0,21-0,50$ & Efek rendah \\
\hline 3 & $.0,51-1,00$ & Efek sedang \\
\hline 4 & $>1,00$ & Efek tinggi \\
\hline
\end{tabular}

Pada penelitian meta-analisis ini digunakan 10 jurnal artikel tentang kemampuan berfikir kritis siswa terhadap model pembelajaran matematika.

Tabel 2. Distribusi 10 Jurnal Artikel Subjek Penelitian

\begin{tabular}{|c|c|c|c|}
\hline Nama & Judul & Jurnal & Akreditasi \\
\hline $\begin{array}{l}\text { Ratnawati, D., } \\
\text { Handayani, I., \& Hadi, } \\
\text { W. }\end{array}$ & $\begin{array}{l}\text { Pengaruh } \\
\text { Pembelajaran Podel } \\
\text { Berbantu Question Card } \\
\text { terhadap Kemampuan } \\
\text { Berpikir Kritis Matematis } \\
\text { Siswa SMP }\end{array}$ & $\begin{array}{l}\text { Jurnal Pendidikan } \\
\text { Matematika }\end{array}$ & S3 \\
\hline $\begin{array}{l}\text { Nufus, H., \& Sahputri, } \\
\text { L. D. }\end{array}$ & $\begin{array}{lr}\text { Pengaruh } & \text { Model } \\
\text { Pembelajaran Problem } \\
\text { Based Learning (PBL) } \\
\text { Terhadap Kemampuan } \\
\text { Berpikir Kritis Matematis } \\
\text { Siswa Pada Materi Sistem } \\
\text { Persamaan Linear Dua } \\
\text { Variabel }\end{array}$ & 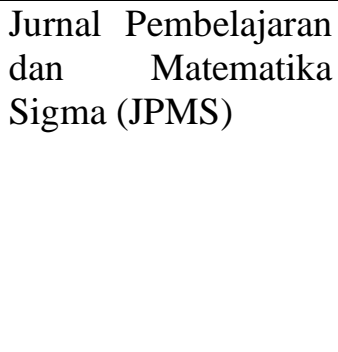 & Scholar \\
\hline $\begin{array}{lll}\text { Dino } & \text { Steven1), } & \text { La } \\
\text { Ndia2), La Arapu3) }\end{array}$ & $\begin{array}{l}\text { Pengaruh Model Problem } \\
\text { Based Learning Terhadap } \\
\text { Kemampuan Berpikir } \\
\text { Kritis Matematis Peserta } \\
\text { Didik Kelas VIII SMP } \\
\text { Negeri } 2 \text { Kendari }\end{array}$ & $\begin{array}{l}\text { Jurnal Penelitian } \\
\text { Pendidikan } \\
\text { Matematika }\end{array}$ & S5 \\
\hline Sitompul1, N. N. S. & $\begin{array}{lr}\text { Pengaruh } & \text { Model } \\
\text { Pembelajaran Problem } & \text { Based Learning Terhadap } \\
\text { Peningkatan Kemampuan } & \text { Berpikir Kritis Matematis } \\
\end{array}$ & $\begin{array}{l}\text { Jurnal Pendidikan } \\
\text { Matematika }\end{array}$ & S5 \\
\hline
\end{tabular}


Meta Analisis: Model Pembelajaran PBL Terhadap Kemampuan Berpikir Kritis Matematis Siswa, Nikmatur Rohmah, Suryo Widodo, Yuni Katminingsih

\begin{tabular}{|c|c|c|c|}
\hline & Siswa SMP Kelas IX & & \\
\hline Nurhasanah;A.Addelia. & $\begin{array}{lr}\text { Pengaruh } & \text { Model } \\
\text { Pembelajaran } & \text { Poblem } \\
\text { Based Learning Terhadap } & \text { Kemampuan Berpikir } \\
\text { Kritis Pada Siswa SMK } \\
\text { Swasta Muhammadiyah } 3 \\
\text { Kuluh Hulu }\end{array}$ & $\begin{array}{lr}\text { Seminar } & \text { Nasional } \\
\text { Matematika } & \text { dan } \\
\text { Terapan } & \end{array}$ & Scholar \\
\hline $\begin{array}{l}\text { Prihono, E. W., \& } \\
\text { Khasanah, F. }\end{array}$ & $\begin{array}{l}\text { Pengaruh Model Problem } \\
\text { Based Learning Terhadap } \\
\text { Kemampuan Berpikir } \\
\text { Kritis Matematis Siswa } \\
\text { Kelas VIII SMP }\end{array}$ & $\begin{array}{l}\text { Jurnal Pendidikan } \\
\text { Matematika }\end{array}$ & S3 \\
\hline $\begin{array}{l}\text { Fedi, S., Gunsi, A. S., } \\
\text { Ramda, A. H. } \quad \text { \& } \\
\text { Gunur, B. }\end{array}$ & $\begin{array}{lr}\text { Pengaruh } & \text { Model } \\
\text { Pembelajaran } & \text { Berbasis } \\
\text { Masalah } & \text { Terhadap } \\
\text { Kemampuan } & \text { Berpikir } \\
\text { Kritis Siswa } & \\
\end{array}$ & $\begin{array}{lr}\text { JKPM } & \text { (Jurnal } \\
\text { Kajian Pendidikan } \\
\text { Matematika) }\end{array}$ & S4 \\
\hline $\begin{array}{l}\text { Utami, C. A., Haji, S., } \\
\text { \& Zamzaili. }\end{array}$ & $\begin{array}{l}\text { Pengaruh Pembelajaran } \\
\text { Problem Based Learning } \\
\text { Dengan Startegi Group } \\
\text { Investigation Terhadap } \\
\text { Kemampuan Berpikir } \\
\text { Kritis Siswa SMKN } 3 \\
\text { Rejang Lebong }\end{array}$ & $\begin{array}{lr}\text { Jurnal Pendidikan } \\
\text { Matematika Raflesia }\end{array}$ & S4 \\
\hline $\begin{array}{l}\text { Arfin, Hudiono, B., \& } \\
\text { Suratman, D. }\end{array}$ & $\begin{array}{l}\text { Pengaruh Problem Based } \\
\text { Learning Terhadap } \\
\text { Kemampuan Berpikir } \\
\text { Kritis Matematis Pada } \\
\text { Materi Gradien di SMP }\end{array}$ & $\begin{array}{l}\text { Jurnal Pendidikan } \\
\text { Dan Pembelajaran }\end{array}$ & Scholar \\
\hline Helmon, A. & $\begin{array}{l}\text { Pengaruh Model Problem } \\
\text { Based Learning (PBL) } \\
\text { Terhadap Kemampuan } \\
\text { Berpikir Kritis Siswa SD }\end{array}$ & $\begin{array}{l}\text { Jurnal Inovasi } \\
\text { Pendidikan Dasar }\end{array}$ & S5 \\
\hline
\end{tabular}

\section{HASIL DAN DISKUSI}

Terdapat Model pembelajaran Prbolem Based Learning (PBL) terhadap kemampuan berfikir kritis siswa.Setelah dilakukan perhitungan menggunakan effect size, dengan melihat rata-rata kelas eksperimen $\left(\overline{\boldsymbol{x}}_{\boldsymbol{E}}\right)$, rata-rata kelas kontrol $\left(\overline{\boldsymbol{x}}_{\boldsymbol{c}}\right)$ dan standar deviasi kelas kontrol $\left(\boldsymbol{S} \boldsymbol{D}_{\boldsymbol{c}}\right)$. Data-data tersebut berasal dari hasil penelitian yang terdapat pada artikel yang diteliti. Berikut adalah tabel datadata perhitungan effect size berdasarkan hasil penelitian yang didapat.

Tabel 3. Nilai effect size Model pembelajaran Matematika

\begin{tabular}{|l|c|c|c|c|c|c|}
\hline Model & $\boldsymbol{n}_{\boldsymbol{E}}$ & $\overline{\boldsymbol{x}}_{\boldsymbol{E}}$ & $\boldsymbol{n}_{\boldsymbol{C}}$ & $\overline{\boldsymbol{x}}_{\boldsymbol{C}}$ & $\boldsymbol{S D}_{\boldsymbol{C}}$ & $\boldsymbol{E S}$ \\
\hline Pembelajaran & 36 & 20.89 & 36 & 19.03 & 2.83 & 0.66 \\
& 18 & 15.83 & 18 & 12.94 & 2.88 & 1.00 \\
& 34 & 59.56 & 33 & 51.52 & 14.91 & 0.53 \\
& 22 & 87.41 & 22 & 67.91 & 4.98 & 3.91 \\
\hline
\end{tabular}




\begin{tabular}{|l|l|l|l|l|l|l|}
\hline & 40 & 79.50 & 36 & 64.03 & 10.26 & 1.50 \\
& 32 & 81.25 & 32 & 75.26 & 11,05 & 0.54 \\
& 24 & 78.89 & 26 & 66.07 & 8.56 & 1.50 \\
& 26 & 78.88 & 25 & 60.32 & 8.43 & 2.20 \\
& 37 & 21.11 & 37 & 15.78 & 8.08 & 0.66 \\
& 27 & 79.28 & 27 & 67.25 & 6.90 & 1,74 \\
\hline
\end{tabular}

Dilihat dari hasil perhitungan effect size (ES) pada tabel 3 dan 4, nilai ES pada model pembelajaran PBL diperoleh nilai terkecil 0.53 sedangkan nilai yang terbesar 3.91 dengan rata-rata 1.47 .

Tabel 4. Nilai rata-rata effect size model pembelajaran

\begin{tabular}{|c|c|}
\hline Model Pembelajaran & $\overline{\boldsymbol{E S}}$ \\
\hline SD & 1.74 \\
\hline SMP & 1,21 \\
\hline SMA & 1,73 \\
\hline RATA-RATA & $\mathbf{1 , 4 7}$ \\
\hline
\end{tabular}

Berdasarkan tabel 4, nilai rata-rata ES model pembelajaran $P B L$ berada pada efek tinggi. Berarti kemampuan berfikir kritis terhadap model pembelajaran Problem Based Learning (PBL) memiliki rata-rata $\mathbf{E S}=\mathbf{1 . 4 7}$ dengan kriteria efek tinggi.

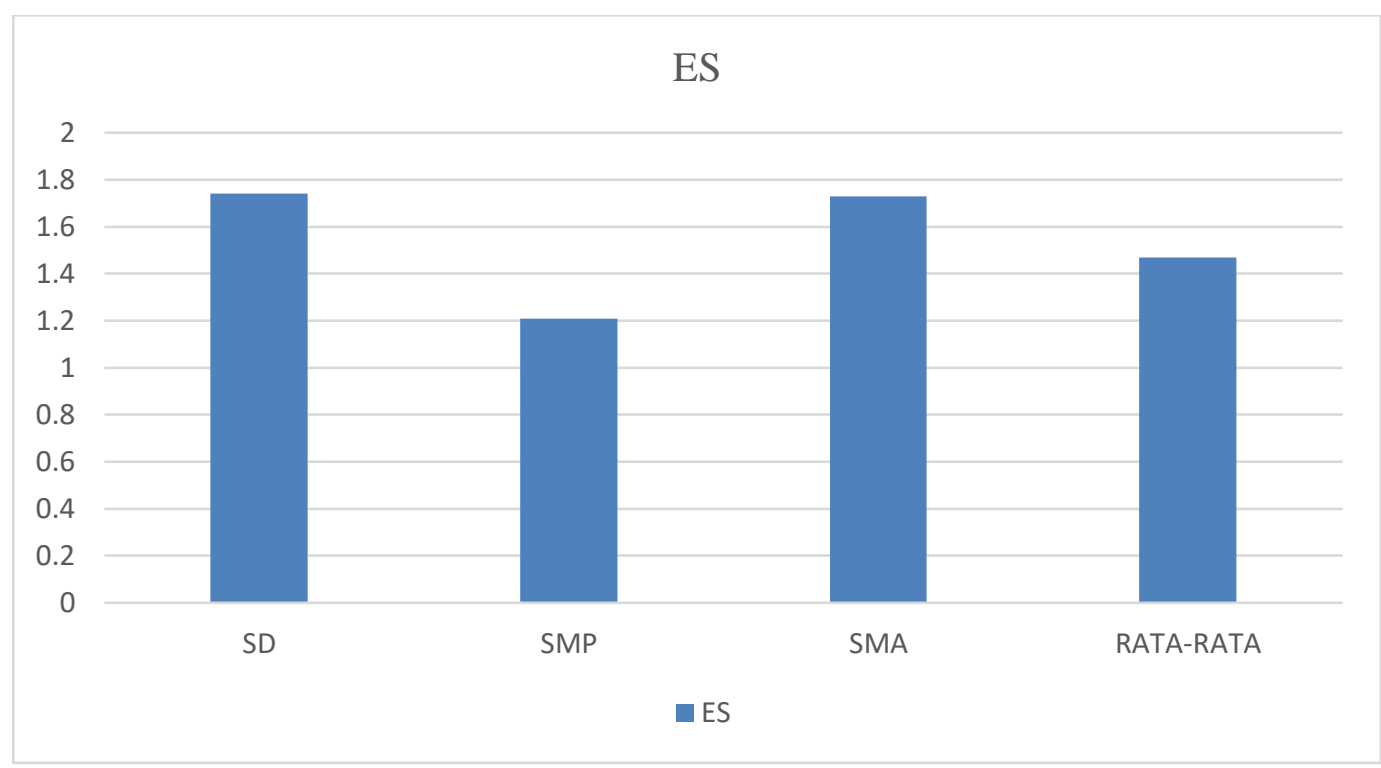

Gambar 1. Diagram nilai rata-rata effect size kemampuan berfikir kritis terhadap model pembelajaran

Rata-rata berpikir kritis siswa yang diajarkan dengan menggunakan model pembelajaran berbasis masalah lebih tinggi daripada kemampuan berpikir kritis siswa yang diajarkan dengan menggunakan pembelajaran konvensional. Ada perbedaan kemampuan berfikir kritis pada kelas eksperimen dan kelas kontrol karena disetiap tahap pembelajaran berbasis masalah siswa dituntut mengembangkan proses berpikir dan menemukan sendiri makna konsep matematika yang dipelajari. 
Meta Analisis: Model Pembelajaran PBL Terhadap Kemampuan Berpikir Kritis Matematis Siswa, Nikmatur Rohmah, Suryo Widodo, Yuni Katminingsih

Dengan pembelajaran berbasis masalah siswa harus proaktif dalam belajar, tidak hanya menyalin, tidak hanya mengikuti alur pikiran guru, tidak hanya mengikuti contoh-contoh tanpa tahu maknanya PBM menstimulus siswa untuk menguras pikiran dan menuangkan pikirannya dalam bentuk tulisan yaitu pernyataan-pernyataan matematika tentang solusi suatu masalah. Masalah tersebut berupa soal uraian dimana hal tersebut menarik perhatian siswa dan memicu siswa untuk berpikir keras, sehingga timbullah kemampuan berpikir kritis dalam diri siswa. Stimulus ini membuat syaraf otak siswa bekerja. Artinya, dalam ranah pikiran, siswa tidak dimanjakan dengan `asupan yang telah jadi` tetapi siswa disuguhi ‘umpan` yang membuat mereka `berjuang` mengolah nalarnya. Karena hal ini dilakukan berulang-ulang, maka terbentuklah `kebiasaan kerja otak` yang kritis. Hal ini menandakan bahwa pembelajaran telah membangun kemampuan berpikir kritis dalam diri siswa. Berdasarkan pengamatan, didapat situasi bahwa ada siswa yang mencoba menyelesaikan soalsoal dari kehidupan nyata dengan caranya sendiri, sesuai dengan tingkat kognitifnya. Secara berkelompok, mereka saling bertukar/menunjukkan desain yang sudah jadi. Terjadi perdebatan di antara anggota kelompok, dan pada akhirnya mereka sepakat (dan menuliskannya) model matematika yang benar (menurut mereka). Hal ini menunjukkan bahwa model PBM sangat merangsang gairah matematis siswa untuk berpikir kritis. Meningkatnya kritik siswa adalah munculnya anggota kelompok yang secara timbal balik memodifikasi hasil pemikiran mereka, saling bertukar pekerjaan, dan menjelaskan mengapa solusi tersebut ditulis. Mereka sepakat tentang solusi mana yang benar dan mana yang salah (Fedi et al., 2018). Dari temuan diatas dapat dikatakan bahwa model pembelajaran berbasis masalah memiliki efek tinggi terhadap kemampuan berfikir kritis.

\section{KESIMPULAN}

Berdasarkan hasil penelitian yang telah dilakukan maka dapat disimpulkan bahwa ada pengaruh kemampuan berfikir kritis terhadap model pembelajaran Problem Based Learning (PBL) yang ditunjukkan dengan efek tinggi.Metode yang peneliti gunakan adalah metode meta analisis dengan menghitung rata-rata Effect Size sebesar 1.47 yang berada pada efek tinggi.

\section{UCAPAN TERIMA KASIH}

Pada kesempatan ini peneliti mengucapkan terimakasih kepada Dr. Aprilia Dwi Handayani, M.Si. selaku kaprodi pendidikan matematika Universitas Nusantara PGRI Kediri, juga kepada Ayahanda tercinta Bapak Jumat dan Ibunda Siti Yulaikah yang telah memberikan bantuan, motivasi, doa yang tulus dan dukungan moral serta material sehingga peneliti dapat menyelesaikan artikel ini.. Akhirnya, peneliti berharap semoga artikel ini dapat bermanfaat bagi kita semua dan menjadi bahan masukan bagi pengembang dunia pendidikan.

\section{REFERENSI}

Agustina, M. D., Putri, A. D., \& Gustiningsih, T. (2018). Model Pembelajaran Problem Based Learning (PBL) Terhadap Kemampuan Berpikir Kritis Matematika Siswa Kelas IX. Jurnal 
Pendidikan Matematika RAFA, 4(2), 164-176. https://doi.org/10.19109/jpmrafa.v4i2.3796 Amalia, N. F., \& Pujiastuti, E. (2016). Kemampuan Berpikir Kritis dan Rasa Ingin Tahu melalui Model PBL. Seminar Nasional Matematika X Universitas Negeri Semarang 2016, 523-531.

Arfin, Hudiono, B., \& Suratman, D. (2015). Pengaruh problem based learning terhadap kemampuan berpikir kritis matematis pada materi gradien di SMP. Jurnal Pendidikan Dan Pembelajaran, $4(3), 1-15$.

Dino Steven1), La Ndia2), L. A. (2019). Pengaruh Model Problem Based Learning Terhadap Kemampuan Berpikir Kritis Matematis Peserta Didik Kelas VIII SMP Negeri 2 Kendari. Jurnal Penelitian Pendidikan Matematika, 7(3), 15-28.

Febrita, I., \& Harni. (2020). Model Problem Based Learning dalam Pembelajaran Tematik Terpadu terhadap Berfikir Kritis Siswa di Kelas IV SD. Jurnal Pendidikan Tambusai, 4(2), 1619-1633.

Fedi, S., , Gunsi, A. S., , Ramda, A. H., \& , \& Gunur, B. (2018). PEngaruh Model Pembelajaran Berbasis Masalah Terhadap Kemampuan Berpikir Kritis Siswa. Jurnal KAJIAN Pendidikan Matematika, 4(1), 11-20. https://doi.org/10.31539/judika.v1i2.413

Fristadi, R., \& Bharata, H. (2015). Meningkatkan Kemampuan Berpikir Kritis Siswa Dengan Problem Based Learning. Seminar Nasional Matematika Dan Pendidikan Matematika UNY, 597-602.

H.Nanda;K, H. E. (2019). Peningkatan Kemampuan Berfikir Kritis Melalui Model Problem Based Learning Pada Muatan Matematika Kelas V SDN Salatiga 01. Jurnal Basicedu, 3(1), 53-59.

Hagi, N. A., Koeswanti, H. D., \& Radia, E. H. (2019). Peningkatan Kemampuan Berpikir Kritis Melalui Model Problem Based Learning Pada Muatan Matematika Kelas V SDN Salatiga 01. Jurnal Basicedu, 5(3), 53-59.

Helmon, A. (2018). PEngaruh Model Problem Based Learning (PBL) Terhadap Kemampuan Berpikir Kritis Siswa SD. Jurnal Inovasi Pendidikan Dasar, 2(1), 38-52.

Nufus, H., \& Sahputri, L. D. (2021). Pengaruh Model Pembelajaran Problem Based Learning ( PBL ) Terhadap Kemampuan Berpikir Kritis Matematis Siswa Pada Materi Sistem Persamaan Linear Dua Variabel. Jurnal Pembelajaran Dan Matematika Sigma(JPMS), 7(1), 12-19.

Nurhasanah;A.Addelia. (2019). Pengaruh Model Pembelajaran Poblem Based Learning Terhadap Kemampuan Berpikir Kritis Pada Siswa SMK Swasta Muhammadiyah 3 Kuluh Hulu. Seminar Nasional Matematika Dan Terapan, 1, 62-64.

Nurlaeli, N., Noornia, A., \& Wiraningsih, E. D. (2018). Pengaruh Model Pembelajaran Problem Based Learning Terhadap Kemampuan Berpikir Kritis Matematis Siswa Ditinjau Dari Adversity Quotient. FIBONACCI: Jurnal Pendidikan Matematika Dan Matematika, 4(2), 145-154. https://doi.org/10.24853/fbc.4.2.145-154

Prihono, E. W., \& Khasanah, F. (2020). Pengaruh Model Problem Based Learning Terhadap Kemampuan Berpikir Kritis Matematis Siswa Kelas Viii Smp. EDU-MAT: Jurnal Pendidikan Matematika, 8(1), 74-87. https://doi.org/10.20527/edumat.v8i1.7078 
Meta Analisis: Model Pembelajaran PBL Terhadap Kemampuan Berpikir Kritis Matematis Siswa, Nikmatur Rohmah, Suryo Widodo, Yuni Katminingsih

Ratnawati, D., Handayani, I., \& Hadi, W. (2020). Pengaruh Model Pembelajaran Pbl Berbantu Question Card Terhadap Kemampuan Berpikir Kritis Matematis Siswa Smp. Edumatica : Jurnal Pendidikan Matematika, 10(01), 44-51. https://doi.org/10.22437/edumatica.v10i01.7683

Sianturi, A., Sipayung, T. N., \& Simorangkir, F. M. A. (2018). Pengaruh Model Problem Based Learning (PBL) Terhadap Kemampuan Berpikir Kritis Matematis Siswa SMPN 5 Sumbul. UNION: Jurnal Ilmiah Pendidikan Matematika, 6(1), 29-42. https://doi.org/10.30738/.v6i1.2082

Simarmata, S. M. (2019). Pengaruh Model Pembelajaran Berbasis Masalah Terhadap Kemampuan Berpikir Kritis Matematis Siswa SMA. Seminar Nasional Matematika Dan Terapan, 1, 107110. https://doi.org/10.54367/cartesius.v2i1.488

Sitompul1, N. N. S. (2021). PENGARUH MODEL PEMBELAJARAN PROBLEM BASED LEARNING TERHADAP PENINGKATAN KEMAMPUAN BERPIKIR KRITIS MATEMATIS SISWA SMP KELAS IX. GAUSS: JURNAL PENDIDIKAN MATEMATIKA, 4(1), 45-54. http://www.jim.unsyiah.ac.id/pendidikan-fisika/article/view/4979

Utami, C. A., Haji, S., \& Zamzaili. (2017). Pengaruh Pembelajaran Problem Based Learning Dengan Strategi Group Investigation Terhadap Kemampuan Berpikir Kritis Siswa SMKN 3 Rejang Lebong. Jurnal Pendidikan Matematika Raflesia, 2(2), 130-138.

Wahyuni, Sri;Anugraheni, I. (2020). Pengruh Model Problem Based Learning Terhadap Kemampuan Berfikir Kritis Siswa Kelas IV Dalam Pembelajaran Tematik. Magistra: Jurnal Keguruan Dan Ilmu Pendidikan, 7(2), 73-82.

Widodo, S., Katminingsih, Y., \& ... (2021). Meta analisis: pengaruh model pembelajaran berdasarkan masalah terhadap kemampuan berpikir kreatif. Indonesian Journal of ..., 1, 567-577. https://doi.org/10.5281/zenodo.4559716

Yanti, O. F., \& Prahmana, R. C. I. (2017). Model Problem Based Learning, Guided Inquiry, dan Kemampuan Berpikir Kritis Matematis. Jurnal Review Pembel.ajaran Matematika, 2(2), 120 130. https://doi.org/10.15642/jrpm.2017.2.2.120-130. 